\title{
Assessment of heavy metals profile in feathers of birds from Kano metropolis, Nigeria, in 2019
}

\author{
Ali Sani ${ }^{12^{*}}{ }^{(\mathbb{D})}$, Ibrahim Lawal Abdullahi ${ }^{1}$, Tasiu Salmanu ${ }^{1}$ \\ ${ }^{1}$ Department of Biological Sciences, Bayero University, PMB 3011, Kano, Nigeria \\ ${ }^{2}$ Department of Instrument Science and Engineering, School of Electronic, Information and Electrical Engineering, Shanghai Jiao Tong \\ University, Shanghai, 200240, China.
}

\begin{abstract}
Background: Contamination by heavy metals has been a major threat locally, regionally, and globally because it affects the structural and functional properties of an environment. The aim of the study was to assess the concentration of heavy metals $(\mathrm{Pb}, \mathrm{Cd}, \mathrm{Cr}$, and $\mathrm{Mn})$ in the feathers of bird species sampled from three areas in Kano metropolis, Nigeria.

Methods: Fifteen samples of birds' feathers were collected from industrial, residential, and commercial areas using mist-nets which were randomly placed to catch passerine birds, early in the morning from 6a.m. to 8a.m. The collected samples were then digested and subjected to atomic absorption spectrophotometry to determine $\mathrm{Pb}, \mathrm{Cd}, \mathrm{Cr}$, and $\mathrm{Mn}$.

Results: The highest concentrations of heavy metals in the birds' feathers were observed in site A (Sharada) followed by site B (Kurmi market) and site C (Rijiyar Lemo), however, the difference in the concentrations of heavy metals between the study areas was not statistically significant $(P>0.05)$. $\mathrm{Pb}$ had the highest concentration followed by $\mathrm{Cd}, \mathrm{Cr}$, and $\mathrm{Mn}$. The highest concentrations of metals were found in the feathers of cattle egret $(\mathrm{Pb}=89 \mathrm{ppm}, \mathrm{Cd}=45 \mathrm{ppm}, \mathrm{Mn}=0.022 \mathrm{ppm})$, mallard drake $(\mathrm{Pb}=78$ $\mathrm{ppm})$, hen $(\mathrm{Cd}=41 \mathrm{ppm})$, duck $(\mathrm{Cr}=2.75 \mathrm{ppm})$, $\operatorname{rooster}(\mathrm{Mn}=0.024 \mathrm{ppm})$, and guinea fowl $(\mathrm{Cd}=41$ ppm), respectively.

Conclusion: The birds' feathers contained various levels of heavy metals which greatly reflect the nature of the sites. Sharada industrial area (site A) recorded the highest concentrations of metals indicating slight metal contamination in the birds' feathers especially in site A.

Keywords: Birds, Feathers, Metals, Monitoring, Pollution

Citation: Sani A, Lawal Abdullahi I, Salmanu T, Assessment of heavy metals profile in feathers of birds from Kano metropolis, Nigeria, in 2019. Environmental Health Engineering and Management Journal 2020; 7(4): 257-262. doi: 10.34172/EHEM.2020.30.
\end{abstract}

\section{Article History:}

Received: 3 August 2020

Accepted: 4 October 2020

ePublished: 11 November 2020

\section{Introduction}

Heavy metals contamination in the world has been considered as a major threat because it affects the properties of an environment both structurally and functionally $(1,2)$. The toxicity profile of such metals influence the performance of many crucial organs such as the central nervous system (3). Many studies have been conducted to ascertain heavy metals occurrence, accumulation, and distribution in addition to other pollutants from natural and anthropogenic activities $(1,4)$. Living organisms at individual and population levels have been used as bioindicators at various trophic levels to obtain information on the extent of exposure, contamination, and effects of chemical pollutants $(5,6)$. Various species of bird including heron and egret have been widely used in biological monitoring of environmental pollution because of their position in the food chain. Thus, having occupied a high level in the food chain makes them exposed to a wide range of pollutants $(7,8)$. Several studies have evaluated the accumulation of heavy metals in organs of bird species $(5,9)$ including eggs $(4,10)$, eggshells $(11)$, feathers $(10,12)$, and prey samples (13). The studies have been performed on various bird species and have generated valuable data on the spatial and temporal distribution of heavy metals (4). One of the non-destructive biomonitoring tools is bird's feathers which have been known to have a potential in assessing the health of local ecosystems. Recently, several studies have used hair and feathers as nondestructive techniques to determine the concentrations of heavy metals and organic pollutants (8). Hence, biomonitoring of environmental pollutants including heavy metals in some species from a designated area could be used to assess the health of the species, as well as the concentration of pollutants 
in their environment (14). There have been very little efforts and information on environmental pollution in Kano possibly because of less biological monitoring strategies. This is despite the huge population of the state with enormous industrial and related activities taking place in the state which produce large tons of waste and pollutants. These necessitate the need to narrow the gap by employing some biological indicators of environment to assess the condition and contamination or pollution status. Kano is the most populous and densely populated state in Northern Nigeria. The state has many settlements and localities that fall under the categories of residential, commercial, and industrial areas. The aim of the study was to assess the concentration of heavy metals including lead $(\mathrm{Pb})$, cadmium $(\mathrm{Cd})$, chromium $(\mathrm{Cr})$, and manganese $(\mathrm{Mn})$ in the feathers of bird species sampled from three areas in Kano metropolis.

\section{Materials and Methods \\ Study area}

The study was conducted in Kano State located in the northern part of Nigeria. Kano State has an estimated land area of $43070 \mathrm{~km}^{2}$ and population of 9383682 million people according to 2006 census. It is located between longitude $100^{\circ} 25 \mathrm{~N}$ and $130^{\circ} 53 \mathrm{~N}$ and latitude $70^{\circ} 10 \mathrm{E}$ and $100^{\circ} 35 \mathrm{E}$, with an altitude of $400-800 \mathrm{~m}$ above the sea level (Figure 1). The birds' feathers samples were collected from three different urban areas of Kano including Sharada, Rijiyar Lemo, and Kurmi market. The areas were selected based on the peculiar and characteristic activities which were industrial (Sharada), residential (Rijiyar lemo), and commercial (Kurmi market), respectively, as prescribed by the State Ministry of Land and Survey. The study was done between September and October 2019.

\section{Sample collection}

Fifteen different samples of birds' feathers were collected from the sampling sites using mist-nets which were randomly placed to catch passerine birds, early in the morning between $6 \mathrm{AM}$ to $8 \mathrm{AM}$. The mounted mist-nets were checked for possible catch after every 20 minutes. Body feathers were collected from the birds captured including insectivorous, omnivorous, granivorous, and nectarivorous birds. Ringing and morphometric measurements were not recorded so as to prevent further stress on the captured birds. Few feathers were collected from each bird and they were immediately released (15).

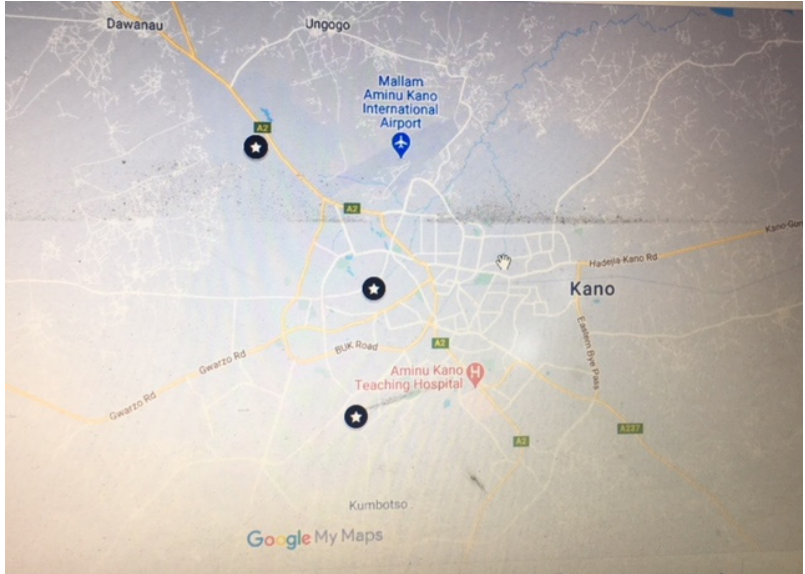

Figure 1. Map of the study area and sampling sites.

The birds images were captured using a digital camera and identified using identification guide of Tropical Wildlife Field Guide: Birds A4 (16).

\section{Reagents and chemicals}

Glasswares and plastics were washed, rinsed many times with tap water, and then, soaked in 5\% nitric acid solution for $24 \mathrm{hr}$ followed by rinsing with deionized water (17). Analytical grades of nitric acid (65\%, Sigma Aldrich) and perchloric acid (70\%, Sigma Aldrich) were used for sample preparation. Standard solutions for calibration of $\mathrm{Pb}, \mathrm{Cr}$, $\mathrm{Cd}$, and $\mathrm{Mn}$ were prepared from $1000 \mathrm{mg} / \mathrm{L}$ standard stock solution of GFS Fishers' AAS Reference Standard. All the solutions were prepared in distilled water. Dilution correction method was applied for samples diluted or concentrated during analysis. These stock solutions were serially diluted to provide concentrations as presented in Table 1 (17).

\section{Sample treatment and analysis}

After collecting the body feathers from the birds, they were washed using alternating distilled water and acetone three times to remove possible contaminants. The samples were then air-dried before oven drying at $105^{\circ} \mathrm{C}$ for 2 hours. The feathers were subsequently cut into smaller pieces using a stainless steel scissors to facilitate the acid digestion process. The acid composed of a mixture of concentrated perchloric acid $\left(\mathrm{HCIO}_{4}\right)$ and nitric acid $\left(\mathrm{HNO}_{3}\right)$ with the ratio of 1:4 by volume (aqua regia). One gram of the feathers samples was added to the acid mixture for complete digestion. The digestion was stopped when

Table 1. Working conditions for determining the heavy metals concentration using atomic absorption spectrophotometer

\begin{tabular}{lcccccccc}
\hline Metals & $\begin{array}{c}\text { Calibration Concentrations } \\
(\mathbf{p p m})\end{array}$ & Wavelength $(\mathbf{n m})$ & $\begin{array}{c}\text { Slit Width } \\
(\mathbf{n m})\end{array}$ & $\begin{array}{c}\text { Detection Limit } \\
(\mathbf{p p m})\end{array}$ & $\begin{array}{c}\text { Lamp Current } \\
(\mathbf{m A})\end{array}$ & $\begin{array}{c}\text { Linear Range } \\
(\mathbf{m g} / \mathbf{L})\end{array}$ & $\begin{array}{c}\text { Flame Type } \\
(\mathbf{c o l o r})\end{array}$ & $\begin{array}{c}\text { Recovery } \\
(\mathbf{\%})\end{array}$ \\
\hline $\mathrm{Mn}$ & $0,0.001,0.01,0.1$ & 279.5 & 0.7 & 0.001 & 6.5 & 2.50 & $\mathrm{~A}-\mathrm{A}, \mathrm{lean} / \mathrm{blue}$ & 75 \\
\hline $\mathrm{Cd}$ & $0,15,30,45$ & 228.80 & 0.7 & 0.01 & 2 & 2.00 & $\mathrm{~A}-\mathrm{A}$, lean/blue & 73 \\
\hline $\mathrm{Cr}$ & $0,1,2,3$ & 357.90 & 0.7 & 0.01 & 2 & 5.00 & $\mathrm{~A}-\mathrm{A}, \mathrm{rich} / \mathrm{yellow}$ & 89 \\
\hline $\mathrm{Pb}$ & $0,30,60,90$ & 283.30 & 0.7 & 0.08 & 5 & 20.00 & $\mathrm{~A}-\mathrm{A}$, lean/blue & 90 \\
\hline
\end{tabular}


a colourless solution was obtained and it was evaporated to dryness. The resulting solution was diluted to 25.0 $\mathrm{mL}$ with deionized water. The solutions were allowed to cool, filtered by Whatman filter paper 42 into a $100 \mathrm{~mL}$ calibrated flask, and were diluted up to the mark. The sample solution was analyzed for $\mathrm{Cd}, \mathrm{Cr}, \mathrm{Pb}$, and $\mathrm{Mn}$ using Flame Atomic Absorption Spectrophotometer (210 VGP, Buck Scientific, East Norwalk, USA) (17).

Data quality assurance/quality control (QA/QC)

Method validation was performed by assessing several analytical figures of merit including linearity and range, precision, limit of detection (LoD), limit of quantification (LoQ) and accuracy, according to International Conference on Harmonisation (ICH) (18). Sensitivity of analytical methods was done according to the ICH (18) and described by the LoD and LoQ $(19,20)$. The precision was measured as relative standard deviation of the concentration in the study. The measurements were done under conditions of repeatability and intermediate precision (19). The accuracy of the process was determined by calculating recoveries of $\mathrm{Cd}, \mathrm{Cr}, \mathrm{Pb}$, and $\mathrm{Mn}$. According to the ICH (19) for determining the recoveries, the spiking technique was used. All analytical steps were performed in three replicates with three different concentrations of $\mathrm{Cd}$, $\mathrm{Cr}, \mathrm{Pb}$, and $\mathrm{Mn}(19,20)$.

\section{Statistical analysis}

The differences between groups were determined using analysis of variance (ANOVA) considering significance level of 5\%. Data were analyzed using SigmaStat 3.5 statistical software.

\section{Results}

Mean concentration of all metals (ppm) in the birds' feathers sampled from three sites in Kano metropolis, 2019 are presented in Figure 2.

Figure 3 shows $\mathrm{Pb}$ concentration across the sampling sites for all samples. In site A, cattle egret had the highest concentration of $\mathrm{Pb}(89 \mathrm{ppm})$ while sunbird had the

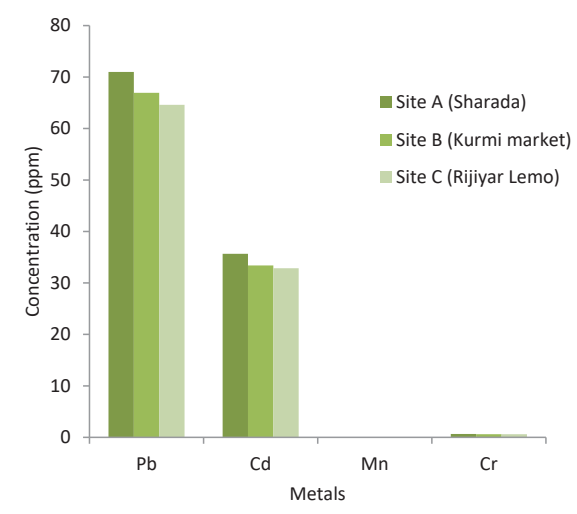

Figure 2. Mean concentration of all metals (ppm) in the birds' feathers sampled from three sites in Kano metropolis, 2019.

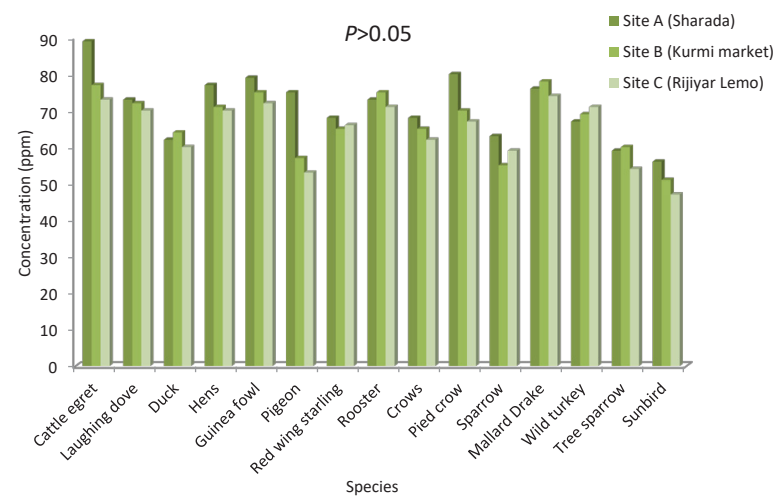

Figure 3. Concentration of $\mathrm{Pb}(\mathrm{ppm})$ in the birds' feathers sampled from Kano metropolis, 2019.

lowest one (56 ppm). Mallard drake had the highest concentrations of 78 and $74 \mathrm{ppm}$ and sunbird had the lowest concentrations of 51 and $47 \mathrm{ppm}$ in site B and C, respectively. No statistical differences were found between the sites in terms of the concentration of $\mathrm{Pb}$ among the bird species $(P>0.05)$.

Figure 4 shows $\mathrm{Cd}$ concentration across the sampling sites for all samples. In site $A$, cattle egret had the highest concentration of $\mathrm{Cd}$ (45 ppm) while sunbird had the lowest one (20 ppm). In site $B$, hen had the highest concentration of Cd (41 ppm) while sunbird had the lowest one (23 ppm). In site $C$, guinea fowl had the highest concentration of Cd (41 ppm) while sunbird had the lowest one (21 ppm). No statistical differences were found between the sites in terms of the concentration of $\mathrm{Cd}$ among the bird species $(P>0.05)$.

Figure 5 shows Mn concentration across the sampling sites for all samples. In site $\mathrm{A}$, rooster had the highest concentration of $\mathrm{Mn}(0.024 \mathrm{ppm})$ while red winged starling had the lowest one $(0.001 \mathrm{ppm})$. In site $\mathrm{B}$, cattle egret had the highest concentration of $\mathrm{Mn}(0.022 \mathrm{ppm})$ while red winged starling had the lowest one (0.001 ppm). In site $\mathrm{C}$, rooster had the highest concentration of $\mathrm{Mn}$ $(0.019 \mathrm{ppm})$ while mallard drake had the lowest one (0.001 $\mathrm{ppm})$. No statistical differences were found between the sites in terms of the concentration of Mn among the bird species $(P>0.05)$.

Figure 6 shows Cr concentration across the sampling sites for all samples. Duck had the highest concentrations of $2.75,2.67$, and $2.55 \mathrm{ppm}$ while tree sparrow had the lowest concentrations of $0.04,0.02$, and $0.02 \mathrm{ppm}$ in sites $\mathrm{A}, \mathrm{B}$, and C, respectively. No statistical differences were found between the sites in terms of the concentration of $\mathrm{Cr}$ among the bird species $(P>0.05)$.

\section{Discussion}

The present study demonstrated the concentration of some toxic metals in feathers of birds across various sites in Kano metropolis including industrial, commercial, and 


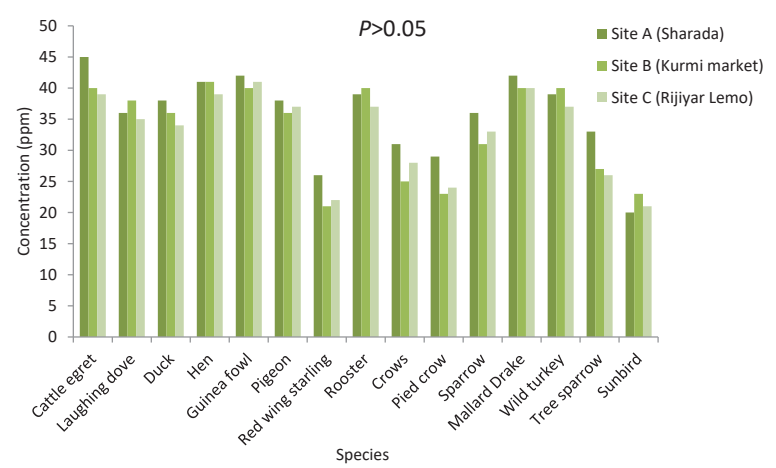

Figure 4. Concentration of $\mathrm{Cd}$ (ppm) in the birds' feathers sampled from Kano metropolis, 2019.

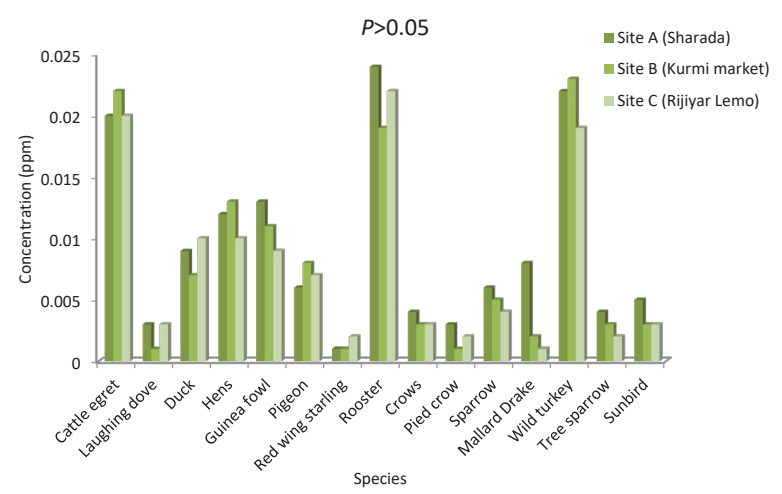

Figure 5. Concentration of $\mathrm{Mn}$ (ppm) in the birds' feathers sampled from Kano metropolis, 2019.

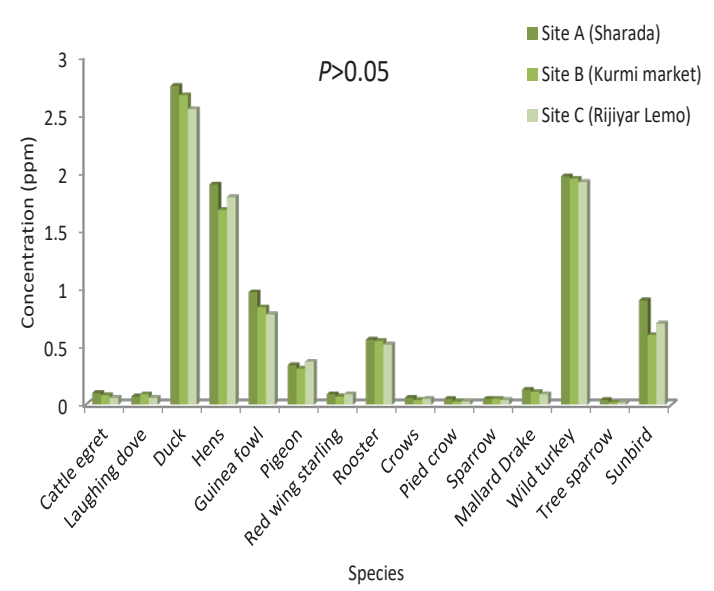

Figure 6. Concentration of $\mathrm{Cr}$ (ppm) in the birds' feathers sampled from Kano metropolis, 2019.

residential areas as seen in Figure $1 . \mathrm{Pb}$ had the highest concentration followed by $\mathrm{Cd}, \mathrm{Cr}$, and $\mathrm{Mn}$ as presented in Figure 2. Similarly, Morrissey et al found out that among the metals detected in dipper feather samples, $\mathrm{Pb}$ had the highest concentration followed by $\mathrm{Mn}$ and $\mathrm{Cd}$ (21).

The highest concentration of metals in feathers was observed in site A (Sharada) followed by site B (Kurmi market) and site C (Rijiyar Lemo), however, the difference was not statistically significant $(P>0.05)$. Similarly, no significant difference was found between the concentration of metals among the bird species $(P>0.05)$. The differences in the concentration of $\mathrm{Pb}, \mathrm{Mn}, \mathrm{Cd}$, and $\mathrm{Cr}$ between the three study sites could be attributed to different local contamination, pollution, or accumulation of metals in the diet of birds foraging in different localities. Site A is an industrial area which is characterized by discharge of pollutants into the environment and could contain a high burden of metals. These might be responsible for the overburden of $\mathrm{Pb}, \mathrm{Cr}, \mathrm{Cd}$, and $\mathrm{Mn}$ in the birds' feathers. However, site $\mathrm{B}$ and $\mathrm{C}$ are commercial and residential areas, respectively, which could have lower levels of pollutants compared to an industrial area (site A), hence, the lower concentrations of metals were recorded in these areas. Similarly, Eens et al has reported that the feathers of great tit nestlings contained significantly higher concentrations of $\mathrm{Pb}$ and lower concentrations of $\mathrm{Zn}$ in the polluted site compared to the reference site. However, there was no significant differences in the concentrations of $\mathrm{As}, \mathrm{Cd}$, and $\mathrm{Cu}$ between the polluted and reference sites $(P>0.05)$, which is consistent with the results of the present study (22). Cattle egret and mallard drake feathers contained the highest concentration of $\mathrm{Pb}$ while sunbird had the lowest one as seen in Figure 3. Jayakumar and Muralidharan reported high concentration of $\mathrm{Cu}(53.31 \pm 23.19 \mathrm{ppm})$ in little egret followed by cattle egret with concentration of $16.27 \pm 9.83 \mathrm{ppm}$ in liver (23). Hen and guinea fowl feathers recorded the highest concentration of $\mathrm{Cd}$ while sunbird revealed the lowest one as seen in Figure 4. The feathers of rooster contained the highest concentration of Mn while red wing starling had the lowest one as shown in Figure 5. Duck had the highest concentration of Cr while tree sparrow showed the lowest one as shown in Figure 6. Some other studies have revealed various degrees of metal contamination in the feathers of birds in polluted or non-polluted sites. Dauwe et al reported that great tit nestling (Parusmajor) from the site closest to the pollution source had significantly higher concentrations of Ag, As, $\mathrm{Hg}$, and $\mathrm{Pb}$ in their feathers than those from the other sites (24). In addition, the concentration of metals in the feathers of nestlings were found to be significantly higher in the polluted site for most of the evaluated metals, which are comparable with those found in the earlier studies conducted along the same pollution gradient $(25,26)$. The concentrations of $\mathrm{Cd}, \mathrm{Pb}$, and $\mathrm{Cu}$ in the feathers of great and blue tit were significantly higher in the polluted site than those in the reference site (22). $\mathrm{Cd}, \mathrm{Ni}, \mathrm{Cu}, \mathrm{Hg}$, and Se were evaluated in the birds' feathers and their concentration exceeded the baseline concentrations found in the literature (27).

Many studies have been conducted on prey of birds and seabirds and have indicated higher accumulation of metals in feathers and other tissues (28-31). Several other studies have demonstrated accumulation of heavy metals in organs of bird species (32-34). 
Heavy metals get into the keratinous structure of feathers when entered into the bloodstream during growth. Though, most metals could be deposited on the surface of the feathers in a quantity higher than the endogenous amounts of deposition (35). The heavy metals burden in the body of nestlings can be ascertained by the growing feathers. Interestingly, the accumulation of some essential trace elements could be regulated homeostatically to keep their concentrations in internal tissues physiologically balanced (36).

Contamination of feathers by exogenous heavy metals could be caused by their excretion from uropygial gland on feathers during preening or deposition from anthropogenic activities (37). Exogenous contamination has been identified as one of the major sources of heavy metals burden in birds' feathers which could be an important path for accumulation of heavy metals in birds' feathers $(25,38,39)$. Such contamination can increase the concentration of most heavy metals in the birds' feathers after their formation (40) and specifically to parts of the feathers that are exposed to the external environment. De Luca-Abbott et al stated that that diet had significantly affected the concentration of accumulated pollutants in Ardeids (41). Burger et al also reported that differences in metal concentrations between different sites could be due to differences in local exposure, atmospheric deposition, or foraging regimes of bird species (42). To support this, Dauwe et al found a positive correlation between feathers of great tit nestlings and caterpillars of lepidoptera acting as their prey for $\mathrm{As}$ and $\mathrm{Pb}(24)$.

\section{Conclusion}

The bird's feathers contained various levels of heavy metals, among which $\mathrm{Pb}$ had the highest concentration followed by $\mathrm{Cd}, \mathrm{Cr}$ and $\mathrm{Mn}$. Feathers of cattle egret, mallard drake, hen, duck, rooster, and guinea fowl had the highest concentration of metals. The degree of fluctuations of the metals level reflects greatly the nature of the sites, whereby site A (Sharada industrial area) with a relative degree of pollution recorded the highest levels of metals. These results indicate slight metal contamination in the birds' feathers especially in site A.

\section{Acknowledgements}

The authors would like to gratitude the staff of Department of Biological Sciences, Bayero University, Kano, for supporting this study.

\section{Ethical issues}

The authors certify that all data collected during the study are as stated in the manuscript, and no data from the study has been or will be published separately elsewhere. Ethical approval was obtained from Department of Biological Sciences, Bayero University, Kano, Nigeria (Ethical code:
BUK/BS/VOL.1/00311).

\section{Competing interests}

The authors declare that they have no conflict of interests.

\section{Authors' contributions}

The authors all contributed and involved actively in the problem analysis, experiments design and execution, data collection and analysis, manuscript preparation and approval.

References

1. Qadir A, Malik RN, Husain SZ. Spatio-temporal variations in water quality of Nullah Aik-tributary of the river Chenab, Pakistan. Environ Monit Assess 2008; 140(1-3): 43-59. doi: 10.1007/s10661-007-9846-4.

2. Qadir A, Malik RN. Assessment of an index of biological integrity (IBI) to quantify the quality of two tributaries of river Chenab, Sialkot, Pakistan. Hydrobiologia 2009; 621(1): 127-53. doi: 10.1007/s10750-008-9637-0.

3. Lee CS, Li X, Shi W, Cheung SC, Thornton I. Metal contamination in urban, suburban, and country park soils of Hong Kong: a study based on GIS and multivariate statistics. Sci Total Environ 2006; 356(1-3): 45-61. doi: 10.1016/j.scitotenv.2005.03.024.

4. Burger J, Gochfeld M. Metal levels in eggs of common terns (Sterna hirundo) in New Jersey: temporal trends from 1971 to 2002. Environ Res 2004; 94(3): 336-43. doi: 10.1016/ s0013-9351(03)00081-1.

5. Kojadinovic J, Bustamante P, Le Corre M, Cosson RP. Trace elements in three marine birds breeding on Reunion Island (Western Indian ocean): part 2-factors influencing their detoxification. Arch Environ Contam Toxicol 2007; 52(3): 431-40. doi: 10.1007/s00244-005-8225-9.

6. Covaci A, Tutudaki M, Tsatsakis AM, Schepens P. Hair analysis: another approach for the assessment of human exposure to selected persistent organochlorine pollutants. Chemosphere 2002; 46(3): 413-8. doi: 10.1016/s00456535(01)00065-0.

7. Burger J. Metals in avian feathers: bioindicators of environmental pollution. Rev Environ Contam Toxicol 1993; 5: 203-11.

8. Burger J. Heavy metal and selenium levels in feathers of herring gulls (Larus argentatus): differences due to year, gender, and age at Captree, Long Island. Environ Monit Assess 1995; 38(1): 37-50. doi: 10.1007/bf00547125.

9. Elliott JE, Scheuhammer AM. Heavy metal and metallothionein concentrations in seabirds from the Pacific coast of Canada. Mar Pollut Bull 1997; 34(10): 794-801. doi: 10.1016/s0025-326x(97)00034-9.

10. Fasola M, Movalli PA, Gandini C. Heavy metal, organochlorine pesticide, and $\mathrm{PCB}$ residues in eggs and feathers of herons breeding in northern Italy. Arch Environ Contam Toxicol 1998; 34(1): 87-93. doi: 10.1007/ s002449900289.

11. Ayaş Z. Trace element residues in eggshells of grey heron (Ardea cinerea) and black-crowned night heron (Nycticorax nycticorax) from Nallihan Bird Paradise, Ankara-Turkey. Ecotoxicology 2007; 16(4): 347-52. doi: 10.1007/s10646007-0132-6.

12. Movalli PA. Heavy metal and other residues in feathers of laggar falcon Falco biarmicus jugger from six districts of Pakistan. Environ Pollut 2000; 109(2): 267-75. doi: 10.1016/ 
s0269-7491(99)00258-4.

13. Zhang Y, Ruan L, Fasola M, Boncompagni E, Dong Y, Dai $\mathrm{N}$, et al. Little Egrets (Egretta garzetta) and trace-metal contamination in wetlands of China. Environ Monit Assess 2006; 118(1-3): 355-68. doi: 10.1007/s10661-006-1496-4.

14. Erwin RM, Custer T. Herons as indicators. In: Kushlan JA, Hafner H. Heron Conservation. London: Academic. 2000; p. 311.

15. Grúz A, Mackle O, Bartha A, Szabó R, Déri J, Budai P, et al. Biomonitoring of toxic metals in feathers of predatory birds from eastern regions of Hungary. Environ Sci Pollut Res Int 2019; 26(25): 26324-31. doi: 10.1007/s11356-019-05723-9.

16. Dean R. Tropical Wildlife Field Guide: Birds. US: RainforestPublications; 2001.

17. Sani A, Gaya MB, Abubakar FA. Determination of some heavy metals in selected cosmetic products sold in kano metropolis, Nigeria. Toxicol Rep 2016; 3: 866-9. doi: 10.1016/j.toxrep.2016.11.001.

18. European Medicines Agency. ICH Topic Q2 (R1) Validation of Analytical Procedures: Text and Methodology. [cited 2019 Oct 12] Available from: https://www.ema.europa.eu/ en/documents/scientific-guideline/ich-q-2-r1-validationanalytical-procedures-text-methodology-step-5_en.pdf.

19. Gustavo González A, Ángeles Herrador M. A practical guide to analytical method validation, including measurement uncertainty and accuracy profiles. TrAC Trends in Analytical Chemistry 2007; 26(3): 227-38. doi: 10.1016/j.trac.2007.01.009.

20. Taverniers I, De Loose M, Van Bockstaele E. Trends in quality in the analytical laboratory. II. Analytical method validation and quality assurance. TrAC Trends in Analytical Chemistry 2004; 23(8): 535-52. doi: 10.1016/j. trac.2004.04.001.

21. Morrissey CA, Bendell-Young LI, Elliott JE. Assessing tracemetal exposure to American dippers in mountain streams of southwestern British Columbia, Canada. Environ Toxicol Chem 2005; 24(4): 836-45. doi: 10.1897/04-110r.1.

22. Eens M, Pinxten R, Verheyen RF, Blust R, Bervoets L. Great and blue tits as indicators of heavy metal contamination in terrestrial ecosystems. Ecotoxicol Environ Saf 1999; 44(1): 81-5. doi: 10.1006/eesa.1999.1828.

23. Jayakumar R, Muralidharan S. Metal contamination in select species of birds in Nilgiris district, Tamil Nadu, India. Bull Environ Contam Toxicol 2011; 87(2): 166-70. doi: 10.1007/s00128-011-0323-y.

24. Dauwe T, Janssens E, Bervoets L, Blust R, Eens M. Relationships between metal concentrations in great tit nestlings and their environment and food. Environ Pollut 2004; 131(3): 373-80. doi: 10.1016/j.envpol.2004.03.009.

25. Dauwe T, Lieven B, Ellen J, Rianne P, Ronny B, Marcel E. Great and blue tit feathers as biomonitors for heavy metal pollution. Ecol Indic 2002; 1(4): 227-34. doi: 10.1016/ s1470-160x(02)00008-0.

26. Janssens E, Dauwe T, Bervoets L, Eens M. Inter- and intraclutch variability in heavy metals in feathers of great tit nestlings (Parus major) along a pollution gradient. Arch Environ Contam Toxicol 2002; 43(3): 323-9. doi: 10.1007/ s00244-002-0138-2.

27. Weber S. Engagement, Education, and Expectations: The Future of Parks and Protected Areas: Proceedings of the 2015 George Wright Society Conference on Parks, Protected Areas, and Cultural Sites. Hancock, Michigan: George Wright Society; 2016.

28. Denneman WD, Douben PE. Trace metals in primary feathers of the Barn Owl (Tyto alba guttatus) in the Netherlands. Environ Pollut 1993; 82(3): 301-10. doi: 10.1016/0269-7491(93)90133-9.

29. Esselink H, van der Geld FM, Jager LP, Posthuma-Trumpie GA, Zoun PE, Baars AJ. Biomonitoring heavy metals using the barn owl (Tyto alba guttata): sources of variation especially relating to body condition. Arch Environ Contam Toxicol 1995; 28(4): 471-86. doi: 10.1007/bf00211630.

30. Jager LP, Rijnierse FV, Esselink H, Baars AJ. Biomonitoring with the buzzard Buteo buteo in the Netherlands: heavy metals and sources of variation. Journal für Ornithologie 1996; 137(3): 295-318. doi: 10.1007/BF01651071.

31. Kim EY, Ichihashi H, Saeki K, Atrashkevich G, Tanabe S, Tatsukawa R. Metal accumulation in tissues of seabirds from Chaun, northeast Siberia, Russia. Environ Pollut 1996; 92(3): 247-52. doi: 10.1016/0269-7491(96)00007-3.

32. Mateo R, Guitart R. Heavy metals in livers of waterbirds from Spain. Arch Environ Contam Toxicol 2003; 44(3): 398-404. doi: 10.1007/s00244-002-2040-3.

33. Deng H, Zhang Z, Chang C, Wang Y. Trace metal concentration in Great Tit (Parus major) and greenfinch (Carduelis sinica) at the Western Mountains of Beijing, China. Environ Pollut 2007; 148(2): 620-6. doi: 10.1016/j. envpol.2006.11.012.

34. Horai S, Watanabe I, Takada H, Iwamizu Y, Hayashi $\mathrm{T}$, Tanabe S, et al. Trace element accumulations in 13 avian species collected from the Kanto area, Japan. Sci Total Environ 2007; 373(2-3): 512-25. doi: 10.1016/j. scitotenv.2006.10.010.

35. Golden NH, Rattner BA, Cohen JB, Hoffman DJ, RussekCohen E, Ottinger MA. Lead accumulation in feathers of nestling black-crowned night herons (Nycticorax nycticorax) experimentally treated in the field. Environ Toxicol Chem 2003; 22(7): 1517-24.

36. Clarkson TW. Effects general principles underlying the toxic action of metals. In: Friberg L, Nordberg GF, Vouk VB, eds. Handbook of the Toxicology of Metals. General Aspects, vol. 1. Amsterdam: Elsevier Science Publishers; 1986. p. $128-48$.

37. Kim J, Koo TH. Heavy metal concentrations in feathers of Korean shorebirds. Arch Environ Contam Toxicol 2008; 55(1): 122-8. doi: 10.1007/s00244-007-9089-y.

38. Dmowski K. Birds as bioindicators of heavy metal pollution: review and examples concerning European species. Acta Ornithol 1999; 34(1): 1-25.

39. Jaspers V, Dauwe T, Pinxten R, Bervoets L, Blust R, Eens $M$. The importance of exogenous contamination on heavy metal levels in bird feathers. A field experiment with freeliving great tits, Parus major. J Environ Monit 2004; 6(4): 356-60. doi: 10.1039/b314919f.

40. Dauwe T, Bervoets L, Pinxten R, Blust R, Eens M. Variation of heavy metals within and among feathers of birds of prey: effects of molt and external contamination. Environ Pollut 2003; 124(3): 429-36. doi: 10.1016/s0269-7491(03)00044-7.

41. De Luca-Abbott SB, Wong BS, Peakall DB, Lam PK, Young $\mathrm{L}$, Lam MH, et al. Review of effects of water pollution on the breeding success of waterbirds, with particular reference to ardeids in Hong Kong. Ecotoxicology 2001; 10(6): 327-49. doi: 10.1023/a:1012288811808.

42. Burger J, Gochfeld M, Sullivan K, Irons D. Mercury, arsenic, cadmium, chromium lead, and selenium in feathers of pigeon guillemots (Cepphus columba) from Prince William Sound and the Aleutian Islands of Alaska. Sci Total Environ 2007;387(1-3): 175-84. doi: 10.1016/j.scitotenv.2007.07.049. 